\title{
Literasi Awal pada Anak Usia Dini Suku Anak Dalam Dharmasraya
}

\author{
Dian Arsa ${ }^{凶}$ \\ Program Studi Bahasa dan Sastra Indonesia, Fakultas Bahasa dan Sastra, \\ Universitas Negeri Padang
}

\begin{abstract}
This study aims to see how the introduction of early stage literacy for early childhood in one of the Suku Anak Dalam groups in Dharmasraya. The introduction was carried out by a small community called Sahabat Belajar. This research is classified as qualitative research, with analysis of Miles and Huberman. After the results found in this study, the literacy in early childhood Suku Anak Dalam was in accordance with what was expected by the Friends of Learning. Various things can be explored from these children through literacy activities telling, about how they spend their days in the forest as children, how they obtain basic knowledge and learn from the people around them, and how they contact with the environment / nature around them.
\end{abstract}

Keywords: Early Literacy, early childhood, Suku Anak Dalam.

\begin{abstract}
Abstrak
Penelitian ini bertujuan untuk melihat bagaimana pengenalan literasi tahap awal untuk anak usia dini di salah satu kelompok Suku Anak Dalam di Dharmasraya. Pengenalan tersebut dilakukan oleh komunitas kecil bernama Sahabat Belajar. Penelitian ini tergolong penelitian kualitatif, dengan analisis Miles dan Huberman. Setelah Hasil yang ditemukan dalam penelitian ini yaitu, literasi awal pada anak usia dini Suku Anak Dalam telah sesuai dengan apa yang diharapkan oleh Sahabat Belajar. Berbagai hal dapat digali dari anak-anak ini melalui kegiatan literasi bercerita, tentang bagaimana mereka menghabiskan harinya di hutan sebagai anak-anak, bagaimana mereka memperoleh pengetahuan dasar dan belajar dari orangorang di sekitarnya, dan bagaiamana kontaknya dengan lingkungan/ alam sekitar mereka.
\end{abstract}

Kata Kunci: Literasi Awal; Anak Usia Dini; Suku Anak Dalam

@ Jurnal Obsesi Prodi PG-PAUD FIP UPTT 2019

Corresponding author :

Address : Padang, Sumatera Barat

ISSN 2356-1327 (Media Cetak)

Email : dyanarsya70@gmail.com

ISSN 2549-8959 (Media Online) 


\section{PENDAHULUAN}

Literasi menjadi isu penting dalam dekade ini di Indonesia. Setelah Program for International Students Assessment (PISA) mengeluarkan hasil temuannya pada tahun 2010 (Kemendikbud, 2015), Indonesia berada pada posisi 57 dari 65 negara yang diteliti PISA, sebab itu pula muncul Gerakan Literasi Sekolah. Sekolah-sekolah bergiat agar siswasiswanya rajin menyerap informasi, melalui kegiatan-kegiatan yang juga sudah disediakan panduannya oleh pemerintah melalui panduan menjalankan Gerakan Literasi Sekolah.

Begitu juga pada tingkat paling dasar dalam jenjang pendidikan, yaitu Pendidikan Anak Usia Dini. Rohde (Fajriyah, 2018), menyatakan sangat penting untuk memastikan anak-anak memperoleh keterampilan dan kesadaran dini yang mereka butuhkan untuk menjadi pembaca dan penulis yang sukses. Pendapat tersebut menunjukkan bahwa pembelajaran literasi penting dan sangat tepat jika diajarkan pada anak usia dini. Perkembangan literasi pada anak prasekolah berada pada tahap literasi paling dasar.

Merujuk pada definisi dari Kemendikbud (2015), secara etimologi, literasi yang diserap dari bahasa Inggris literacy berasal dari bahasa Latin, littera, yang artinya huruf. Dalam artian luas yaitu kegiatan yang melibatkan pengasaan sistem-sistem tulisan dan konvensikonvensi yang menyertainya. Namun demikian, literasi utamanya berhubungan dengan bahasa dan bagaimana bahasa itu digunakan. Adapun sistem bahasa tulis itu sifatnya sekunder. Manakala berbicara mengenai bahasa, tentunya tidak lepas dari pembicaraan mengenai budaya, karena bahasa itu sendiri merupakan bagian dari budaya. Sehingga pendefinisian istilah literasi tentunya harus mencakup unsur yang melingkup bahasa itu sendiri, yakni situasi sosial budayanya.

Berikutnya, menurut (Badan Pengembangan dan Pembinaan Bahasa, 2016), literasi adalah kemampuan menulis dan membaca, atau pengetahuan/ keterampilan dalam bidang atau aktivitas tertentu. Lebih lanjut, literasi adalah penggunaan praktik-praktik situasi sosial, historis, dan kultural dalam menciptakan dan menginterpretasikan makna melalui teks. Literasi memerlukan setidaknya sebuah kepekaan yang tak terucap tentang hubungan antara konvensi-konvensi tekstual dan konteks penggunaannya serta idealnya kemampuan untuk berefleksi secara kritis tentang hubungan-hubungan itu. Kepekaan yang bermuatan maksud/ tujuan, literasi itu bersifat dinamis/ tidak statis, dan dapat bervariasi dalam kultur sebuah wacana.

Literasi memerlukan serangkai kemampuan kognitif, pengetahuan bahasa tulis dan lisan, pengetahuan tentang genre, dan pengetahuan kultural, dalam artian dibutuhkan kemampuan yang kompleks dalam literasi.

Lebih spesifik, menurut Astuti (Fajriyah, 2018), literasi berarti kemampuan membaca dan menulis serta menggunakan bahasa lisan.

Dapat disimpulkan bahwa literasi merupakan penyerapan informasi berbentuk ilmu pengetahuan dari teks ataupun lisan, untuk menumbuhkembangkan kemampuan kognisi, melalui membaca dan menulis (secara spesifiknya).

Namun definisi tersebut terlalu komplek jika diterapkan dalam penelitian ini. Penelitian ini berfokus pada subjek yang berumur di bawah 6 tahun atau dalam istilahnya Anak Usia Dini (AUD). Pengertian literasi di atas, dapat disederhanakan untuk tingkat anak usia 
dini, yaitu penyerapan informasi melalui apa yang dirasakan lewat pancaindera anak, untuk kemudian dijadikan pengetahuan awal bagi mereka.

Nutbrown \& Claugh (Wartomo, 2017) mengemukakan bahwa pengenalan literasi bagi anak anak usia dini (AUD) mulai dikembangkan. Sebagai contoh di Inggris sejak tahun 1980-an karena para guru dan peneliti melihat jika pentingnya mengenalkan atau membelajarkan literasi membaca dan menulis bagi anak usia dini.

Sependapat dengan itu Menurut Subiyantoro (Wartomo, 2017) pengenalan budaya literasi anak pada dasarnya ia akan menginternalisasikan sistem kaidah yang berhubungan dengan bunyi dan makna secara khusus dan anak memperoleh kemampuan literasi dengan cara yang sangat menakjubkan.

Selanjutnya, Morrison (Wartomo, 2017) mengemukakan bahwa, penguasaan bahasa adalah pembawaan lahir pada semua anak usia dini tanpa memandang budaya dan agamnya. Artinya bahwa sejak lahir sampai dengan usia 6 tahun anak usia dini sudah mempunyai kemampuan dalam literasi, meskipun tidak belajar secara khusus tetapi anak belajar bahasa melalui interaksi dengan lingkungan di mana anak tinggal.

Justice, L.M. (Wartomo, 2017) menyatakan bahwa periode literasi anak mulai dari lahir sampai dengan usia enam tahun. Pada periode tersebut anak-anak usia dini memperoleh pengetahuan tentang membaca dan menulis tidak melalui pengajaran, tetapi melalui perilaku yang sederhana dengan mengamati dan berpartisipasi pada aktivitas yang berkaitan dengan literasi. Pengajaran formal tidak selalu diperlukan untuk mengembangkan literasi sederhana. Dengan mengamati orang yang melakukan aktivitas literasi dan berpartisipasi dengan aktivitas tersebut maka anak usia dini akan memperoleh kemampuan yang merupakan prasyarat penting untuk mengembangkan membaca konvensional.

Jadi dapat disimpulkan bahawa dalam tingkatan Anak Usia Dini (AUD) literasi itu tidak mesti dilalui dengan formal yang dalam hal ini anak-anak tidak harus memperolehnya lewat penyekolahan. Literasi sederhana berkaitan dengan apa yang didapatkan anak pada lingkungannya. Proses mereka berbicara, berinteraksi, dan mengamati aktivitas orang-orang di sekitarnya sudah termasuk dalam literasi sederhana pada AUD.

Berkaitan dengan penjabaran itu, penelitian ini mengulas tentang bagaimana literasi awal pada salah satu kelompok Suku Anak Dalam di Dharmasraya dan bagaimana pengembangan yang dilakukan pegiat sosial Sahabat Belajar (laman Belajar Bersama Sahabat) pada literasi awal untuk Anak Usia Dini Suku Anak Dalam.

Penelitian mendalam tentang Suku Anak Dalam belum banyak dilakukan. Salah satu yang ditemui penulis adalah disertasi Steven Sager pada tahun 2008 (Sager, 2008) yang memuat secara menyeluruh tentang Suku Anak Dalam atau dinamai juga dengan Suku Kubu. Fokus kajian Sager lebih pada adat dan religi Suku Anak Dalam (SAD) yang ada di Bukit Duabelas.

Menurut Sager (Sager, 2008), Suku Kubu atau juga dikenal dengan Suku Anak Dalam atau Orang Rimba adalah salah satu suku minoritas yang hidup di Pulau Sumatra, tepatnya di Provinsi Jambi dan Sumatera Selatan. Secara garis besar di Jambi Suku Anak Dalam hidup di 3 wilayah ekologis yang berbeda, yaitu Orang Kubu yang di utara Provinsi Jambi (sekitaran Taman Nasional Bukit 30), Taman Nasional Bukit 12, dan wilayah selatan Provinsi Jambi (sepanjang jalan lintas Sumatra). Mereka hidup secara 
nomaden dan yang bergantung pada berburu dan meramu.

Menurut tradisi lisan suku Anak Dalam merupakan orang Maalau Sesat, yang lari ke hutan rimba di sekitar Air Hitam, Taman Nasional Bukit Duabelas. Mereka kemudian dinamakan Moyang Segayo. Tradisi lain menyebutkan mereka berasal dari wilayah Pagaruyung, yang mengungsi ke Jambi. Ini diperkuat kenyataan adat suku Anak Dalam punya kesamaan bahasa dan adat dengan suku Minangkabau, seperti sistem kekeluargaan matrilineal.

Secara garis besar di Jambi mereka hidup di 3 wilayah ekologis yang berbeda, yaitu Orang Kubu yang di utara Provinsi Jambi (sekitaran Taman Nasional Bukit 30), Taman Nasional Bukit 12, dan wilayah selatan Provinsi Jambi (sepanjang jalan lintas Sumatra). Mereka hidup secara nomaden dan mendasarkan hidupnya pada berburu dan meramu, walaupun banyak dari mereka sekarang telah memiliki lahan karet dan pertanian lainnya.

Sager menyimpulkan kehidupan Suku Anak Dalam ketika ia melakukan penelitian, sangat mengenaskan seiring dengan hilangnya sumber daya hutan yang ada di Jambi dan Sumatera Selatan. Berdasarkan yang ditinjau di lapangan hutan-hutan yang dulunya 'milik' mereka (dalam artian tempat mereka membangun genah (nama tempat tinggal mereka) dan tempat mereka berpindah-pindah, sekarang telah menjadi lahan sawit. Kata 'sekarang' ini dimulai dari transmigrasi besar-besaran dari zaman Presiden Soeharto dulu. Namun, semakin lama lahan-lahan karet dan sawit memang jauh meluas dari sebelumnya, yang menyebabkan hutan-hutan di wilayah tenpat tinggal Suku Anak Dalam berganti menjadi perkebunan.

Sekarang ini pun, banyak kelompokkelompok Suku Anak Dalam di
Dharmasraya yang mendirikan genahgenah di perkebunan warga dan perusahaan swasta. Beberapa konflik pun telah banyak terjadi akibat ini. Beritaberitanyapun mudah diketahui di berbagia media Nasional. Namun upaya pemerintah dalam pemecahan persoalan tersebut juga telah lama dilakukan. Upaya itu, menurut Menteri Sosial, Khofifah (Henschke, 2017) misalnya dengan membangun rumah untuk Suku Anak Dalam, menyediakan sekolah (meskipun tidak terkhusus), dan berbagai fasilitas lainnya seperti sanitasi untuk mandi dan kebutuhan air bersih, yang semua itu ditujukan untuk menjadikan Suku Anak Dalam sama dengan masyarakat Indonesia lainnya, bukan 'suku terisolasi' sebagaimana yang dikatakan Sager.

Banyak perdebatan dari berbagai kalangan tentang upaya pemerintah tersebut. Berdasarkan reportase (Henschke, 2017), secara umum dari berbagai sisi, kehidupan Suku Anak Dalam dapat disimpulkan sangat memprihatinkan. Upaya-upaya yang dilakukan pemerintah itu tidak berhasil. Meskipun sebagian kecilnya telah memilih untuk menetap dan memiliki agama, namun sebagian besarnya belum mampu untuk tinggal menetap karena memang tidak sejalan dengan tradisi Suku Anak Dalam. Keinginan mereka adalah ketersediaan hutan untuk kehidupan mereka, yang semakin lama hutan-hutan itu semakin menipis.

Di sisi lain, Suku Anak Dalam juga telah banyak berinteraksi dengan masyarakat lainnya di sekitar mereka. Mereka telah berkebun dan menjual hasil kebunnya, membeli peralatan-peralatan dan bahkan motor, namun mereka tetap hidup semi-nomaden di hutan dan perkebunan.

Mereka yang sudah mulai keluar dan berinteraksi dengan masyarakat, sangat membutuhkan pengetahuan dasar seperti 
kemampuan berhitung dan membaca. Untuk itulah, dalam skala permasalahan yang besar pada Suku Anak Dalam, penelitian ini membatasi dengan mengangkat persoalan pada bagaimana literasi awal pada anak-anak usia dini Suku Anak Dalam di salah satu kelompok Suku Anak Dalam yang ada di Dharmasraya.

\section{METODOLOGI}

Penelitian ini tergolong peneltian kualitatif. Subjek yang digunakan dalam penelitian ini adalah anak-anak Suku Anak Dalam dalam rentang Anak Usia Dini (usia 6 tahun ke bawah). Dalam penelitian ini, wilayah yang dilihat adalah wilayah Suku Anak Dalam yang ada di Dharmasraya, Provinsi Sumatera Barat yang berbatasan langsung dengan Provinsi Jambi di bagian selatan.

Suku Anak Dalam di Dharmasraya tersebar dalam beberapa kelompok. Salah satu kelompok yang besar adalah kelompok Marni. Marni dapat dikatakan tetua kelompok yang sekarang kelompoknya tersebar dalam kelompokkelompok kecil, 10-15 orang, di sekitar hutan dan perkebunan sawit di wilayah Dharmasraya.

Teknik pengumpulan data menggunakan wawancara dan observasi partisipasi aktif, di mana peneliti datang ke tempat kegiatan orang yang diamati dan terlibat dalam beberapa kegiatan tersebut. Proses analisis data menggunakan model Miles dan Huberman, yaitu mengumpulkan data, mereduksi, menyajikan, dan menarik kesimpulan berdasarkan data tersebut.

Wawancara dilakukan dengan anggota Sahabat Belajar, terutama Eko sebagai orang yang telah lama bersama Suku Anak Dalam tersebut.

\section{HASIL DAN PEMBAHASAN}

Suku Anak Dalam yang ada di Dharmasraya secara kultural sedikitbanyaknya telah keluar dari isolasi mereka di hutan karena mau tidak mau hutan mereka juga telah berganti dengan perkebunan sawit dan karet. Secara tidak langsung mereka bertemu dengan masyarakat sekitar lainnya. Andri, sebagai pemuda Dharmasraya mengatakan bahwa Suku Anak Dalam sekarang beberapa kelompoknya ada yang membangun genah di perkebunan-perkebunan karet. Kadang muncul berbagai masalah dengan pihak perkebunan yang umumnya dimiliki swasta. Masalah-masalah itu seperti ketika Suku Anak Dalam ini selesai berburu babi, sisa-sisa bagian organ babi yang tidak mereka makan mereka buang di sekitaran kebun, yang setelah beberapa hari mengeluarkan bau tidak sedap. Pengelola kebun di lapangan tentu risih dengan keadaan ini. Namun jika dilihat di sisi lain, Suku Anak Dalam sudah jauh sebelum perkebunan ini ada yang sebelumnya hutan rendah, telah mereka diami. Keterangan ini sesuai dengan reportase yang dilakukan (Henschke, 2017)

Hasil buruan dan hasil hutan seperti jerenang, yang Suku Anak Dalam dapatkan, selain untuk mereka gunakan, juga mereka jual pengepul yang mereka sudah ketahui. Di beberapa kelompok telah memiliki perkebunan sendiri di pinggirpinggir hutan, seperti karet. Kelompok itu telah bisa menyadap dan menjual hasil kebun mereka. Namun kehidupan mereka tetap semi-nomaden. Anak-anak Suku Anak Dalam di Banai ini dapat dikatakan tidak ada yang di sekolah formal. Di bagian Bukit Duabelas Jambi pernah dulu dikelola pendidikan nonformal bernama 'Sokola Rimba oleh Butet Manurung. 
Di salah satu kelompok Marni ini, tepatnya di Batang Bakur, Nagari Banai, Dharmasraya, Eko tinggal bersama Suku Anak Dalam selama kurang lebih 2 tahun. Kelompok ini memanggilnya Dokter Eko karena Eko hampir selalu mengecek kesehatan dan kebersihan Suku Anak Dalam. Memberikan bantuan pada persoalan pengurusan ke pelayanan kesehatan bagi Suku Anak Dalam.

Kelompok Suku Anak Dalam yang Eko masuki, berjumlah sekitar 16 orang, "Terkadang mereka silih berganti masuk, sebelum pindah bersama-sama dalam tradisi Malangun." Secara geografis, hutan Banai masih asri, meskipun beberapa sudah ditanami pohon karet, namun bukan perkebunan permanen. Di area inilah salah satu kelompok Suku Anak Dalam ini bermukim.

Eko sebagai orang dari luar Suku Anak Dalam memberikan perhatian pada Suku Anak Dalam. Dia yang kemudian mengajak beberapa mahasiswa ataupun eks-mahasiswa Unand di Padang, untuk ikut serta memberikan kontribusi bagi Suku Anak Dalam. Selama beberapa kali, kelompok yang kemudian dinamai Sahabat Belajar ini mengunjungi Suku Anak Dalam. Mereka memberikan perhatian terutama pada persoalan literasi anak-anak Suku Anak Dalam.

Meskipun tidak didasarkan pada sistem kurikulum pengajaran yang sistematis, namun dalam hal ini, anggota Sahabat Belajar mencoba menggali pengetahuan sehari-hari anak-anak Suku Anak Dalam, tentang apa kegiatan mereka, kegiatan orang-orang di sekitar mereka. Mengasah kemampuan mereka untuk bercerita tentang apa saja yang mereka lakukan di hutan.

Fase awal, peneliti dan anggota Sahabat Belajar dapat bergabung dengan Suku Anak Dalam melalui Eko, yang sebelumnya sudah lama bersama Suku
Anak Dalam. Kegiatan awal, dilakukan dengan membiasakan Suku Anak Dalam dengan keberadaan peneliti dan anggota Sahabat Belajar.

Interaksi awal dimulai dari orang tua terlebih dahulu. Setelah itu baru melakukan beberapa interaksi kecil dengan anak-anak yang kemudian akan dijadikan subjek dalam penelitian ini. Pada awalnya, tentu anak-anak tersebut tidak terlalu mau diajak berinteraksi. Pola pendekatan yang dilakukan adalah dengan ikut serta melihat mereka bermain ataupun berkegiatan sehari-harinya.

Berdasarkan hasil observasi, kegiatan yang biasa dilakukan anak-anak Suku Anak Dalam (dalam rentang usia 4-6 tahun), mereka bermain di tepian anak sungai yang tidak jauh dari genah (pemukiman mereka). Mereka terkadang menangkap ikan ataupun binatang lainnya seperti kura-kura dan labi-labi dengan menggunakan alat seadaanya atau dengan tangan kosong. Bagi anak laki-laki di bawah 6 tahun, biasanya mereka ikut dengan saudara-saudara mereka yang lebih tua berkeliling hutan, mencari kodok besar ataupun tanaman-tanaman tertentu.

Anak laki-laki Suku Anak Dalam yang berusia di atas 13 tahun biasanya telah ikut berburu dengan ayah mereka. Sedangkan fase sebelum itu mereka bebas bermain di hutan. untuk yang perempuan mereka lebih sering dimintai bantuan oleh ibu mereka dibanding anak laki-laki.

Anak-anak yang tergolong Anak Usia Dini rentang usia 3-6 tahun dalam kelompok ini, sebanyak 8 orang, dan ada 2 orang lagi di bawah rentang usia tersebut. Anak-anak di umur 2 tahun itu terkadang diasuh saudara perempuan mereka yang lebih tua. Berikut tabel kegiatan yang biasa mereka lakukan. 
Tabel 1. Kegiatan anak-anak Suku Anak

Dalam berdasarkan rentang usia.

\begin{tabular}{|c|c|c|c|}
\hline No & $\begin{array}{c}\text { Jenis } \\
\text { Kelamin }\end{array}$ & $\begin{array}{l}\text { Rentang } \\
\text { Usia } \\
\text { ( } \pm \text { tahun) }\end{array}$ & Kegiatan \\
\hline 1 & Laki-laki & $>13$ & $\begin{array}{l}\text { - Ikut berburu ringan } \\
\text { di siang hari dengan } \\
\text { laki-laki dewasa. } \\
\text { - Ikut mencari } \\
\text { tumbuh-tumbuhan } \\
\text { dan buah-buahan } \\
\text { untuk dimakan } \\
\text { ataupun diramu. } \\
\text { - Ikut memasang jerat } \\
\text { ikan di malam hari. }\end{array}$ \\
\hline 2 & Laki-laki & $7-13$ & $\begin{array}{l}\text { - } \text { Bermain } \\
\text { - Berjalan-jalan di } \\
\text { hutan di sekitaran } \\
\text { genah } \\
\text { - Belajar menangkap } \\
\text { ikan di anak sungai } \\
\text { di dalam hutan } \\
\text { tersebut. }\end{array}$ \\
\hline 3 & Laki-laki & $3-6$ & $\begin{array}{l}\text { - Bermain } \\
\text { - Mencari binatang- } \\
\text { binatang yang bisa } \\
\text { dijadikan peliharaan } \\
\text { layaknya mainan, } \\
\text { binatang-binatang } \\
\text { seperti kodok besar, } \\
\text { kura-kura, dan } \\
\text { sebagainya. } \\
\text { - Ikut dengan teman- } \\
\text { teman yang lebih tua, } \\
\text { menangkap ikan di } \\
\text { anak sungai di dalam } \\
\text { hutan tersebut. } \\
\text { Rata-rata anak-anak } \\
\text { Suku Anak Dalam di } \\
\text { usia ini sudah punya } \\
\text { peliharaan seperti } \\
\text { kodok besar atau } \\
\text { anak monyet. }\end{array}$ \\
\hline 4 & Perempuan & $>13$ & $\begin{array}{l}\text { - Membantu ibu } \\
\text { memasak dan } \\
\text { merawat adik } \\
\text { - Terkadang ikut ibu } \\
\text { mencari tumbuhan } \\
\text { untuk diramu }\end{array}$ \\
\hline 5 & Perempuan & $7-13$ & $\begin{array}{l}\text { - Bermain } \\
\text { - Mencari binatang- } \\
\text { binatang yang bisa } \\
\text { dijadikan peliharaan }\end{array}$ \\
\hline
\end{tabular}

\begin{tabular}{|l|l|l|l|}
\hline No & $\begin{array}{c}\text { Jenis } \\
\text { Kelamin }\end{array}$ & $\begin{array}{c}\text { Rentang } \\
\text { Usia } \\
( \pm \text { tahun })\end{array}$ & \multicolumn{1}{|c|}{ Kegiatan } \\
\hline & & & $\begin{array}{l}\text { layaknya mainan, } \\
\text { binatang-binatang } \\
\text { seperti kodok besar, } \\
\text { kura-kura, dan } \\
\text { sebagainya, seperti } \\
\text { anak laki-laki di } \\
\text { rentang usia tersebut. } \\
\text { Sebagian sudah ikut } \\
\text { membantu ibu } \\
\text { memasak dan } \\
\text { merawat adik }\end{array}$ \\
\hline 6 & Perempuan & $3-6$ & $\begin{array}{l}\text { Bermain } \\
\text { Mencari binatang- } \\
\text { binatang yang bisa } \\
\text { dijadikan peliharaan } \\
\text { layaknya mainan, } \\
\text { binatang-binatang } \\
\text { seperti kodok besar, } \\
\text { kura-kura, dan } \\
\text { sebagainya. }\end{array}$ \\
\hline
\end{tabular}

Kegiatan anak-anak tersebut menjadi poin-poin penting dalam menggali literasi mereka melalui bercerita.

Beberapa hari bersama anak-anak Suku Anak Dalam dan mengikuti kegiatan mereka, memberi kedekatan sosial antara peneliti dan anggota Sahabat Belajar dengan anak-anak Suku Anak Dalam. Peluang ini dapat dimanfaatkan dengan memberikan dan menggali bagaimana literasi awal pada anak-anak Suku Anak Dalam.

Anggota Sahabat Belajar mengajak anak usia dini Suku Anak Dalam untuk menggambar. Kertas, pensil, dan pewarna diberikan kepada anak-anak tersebut. Pada tahap awal mereka diberikan kebebasan menggambar apa saja karena secara prinsipnya, menurut Fajriyah (Fajriyah, 2018), literasi awal dapat berupa penyediakan media seperti menggambar yang dapat meningkatkan literasi anak.

Semua anak-anak menggambar di hari pertama literasi itu. Anak-anak tersebut sangat antusias dan serius 
menggambar. Malah mereka tidak menertawakan hasil gambar temantemannya. Mereka sibuk mencoretcoretkan pensil dan pewarna. Mereka diberi kebebasan juga dalam cara memegang pensil dan mereka tidak diajarkan keseragaman dalam memegang pensil sebagaimana di sekolah pada umumnya. Menurut Eko, hal ini dapat memberi pengalaman bagi mereka. Mereka akan menemukan sendiri cara yang terefektif untuk persoalan memegang pensil ini.

Pola pembelajaran yang diberikan anggota Sahabat Belajar pada awal ini lebih kepada kebebasan berimajinasi dan menemukan pemecahan permasalahan sendiri (pembelajaran berbasis pemecahan masalah) seperti yang dilakukan pada tahapan di atas.

Hasil gambar tahap pertama ini, ada dari mereka menggambar wajah, menggambar pohon, dan menggambar rumah (genah), sebagian yang lain masih dalam coret-coretan warna-warni. Pada pertemuan berikutnya, anak-anak tersebut diminta menggambar dari sesuatu yang telah tersedia, seperti menggambar daun, dengan cara menjiplak. Caranya, dengan mengambil sehelai daun yang pinggirannya menarik/bergerigi, lalu daun itu diletakkan di atas kertas kosong, dan anak-anak mengikuti garis tepinya itu sampai terbentuk daun sempurna. Kemudian mereka diminta mewarnainya.

Setelah itu, anak-anak tersebut dengan sendirinya mencoba melakukan hal yang sama namun dengan objek yang berbeda. Mereka mencoba menjiplak tangan mereka sendiri, bahkan kodok besar; peliharaan mereka sendiri, mereka tempelkan pada kertas tersebut, untuk mereka jiplak.

Pertemuan ketiga, mereka diminta menceritakan apa yang telah mereka gambar. Seperti pada subjek penelitian yang bernama Bujang Padek, yang menceritakan tentang gambar-gambarnya. Dua pertemuan berikutnya banyak dihabiskan dengan bercerita karena kondisi cuaca yang sering hujan, maka kurang kondusif melakukan aktifitas di luar.

Pola bercerita ini sesuai dengan teori literasi awal pada anak usia dini, yaitu dengan menggali pengetahuan anak lewat menceritakan pengalaman keseharian yang telah dilakukannnya (Fajriyah, 2018). Misalnya, pada salah satu subjek penelitian bernama Bujang Cilalek, yang bercerita kodok peliharaannya. Ia dimintak bercerita tentang kodoknya tersebut, di mana ia mendapatkannya, makanannya, dan sebagainya. Pada percakapan-percakapan dengan subjek penelitian tersebut, disisipkan beberapa pengetahuan dasar kepada mereka, misalnya kodok itu bertelur, dan kodok yang masih bayi namanya kecebong. Kecebong lebih terlihat seperti ikan daripada kodok.

Cerita-cerita lainnya digali berdasarkan keseharian yang telah mereka lakukan, sesuai dengan tabel kegiatan anak-anak Suku Anak Dalam tersebut. Bagaimana mereka mendapat pengetahuan dari alam dan lingkungan sekitar mereka. Mengetahui cara-cara yang teman-teman dan orang-orang yang lebih tua lakukan. Seperti menangkap ikan dan berburu. Tahap ini menjadi literasi awal yang sangat berpengaruh bagi mereka.

Tahap selanjutnya, barulah mereka diperkenalkan dengan huruf dan angka. Pada penerapannya, anak-anak tidak dibebankan pada proses mengingat bentukbentuk huruf dan angka, namun mereka terlebih dahulu diajarkan berhitung dengan penjumlahan beberapa benda.

Terakhir, baru mereka diajarkan bentuk huruf dan angka, cara pengucapannya, dan mulai menuliskannya. Namun semua itu seharusnya dilakukan dengan berkesinambungan. Peneliti hanya 
mengikuti sampai tahap pengenalan huruf tersebut, sedangkan anggota Sahabat Belajar terus melanjutkan, meskipun dengan jarak waktu yang lama. Itulah beberapa fase atau tahapan yang telah dilalui anak usia dini Suku Anak Dalam menunjukkan bagaimana proses literasi awal pada anak usia dini Suku Anak Dalam.

Berikut beberapa foto penelitian yang diambil oleh Sahabat Belajar (Sahabat Belajar, 2013).

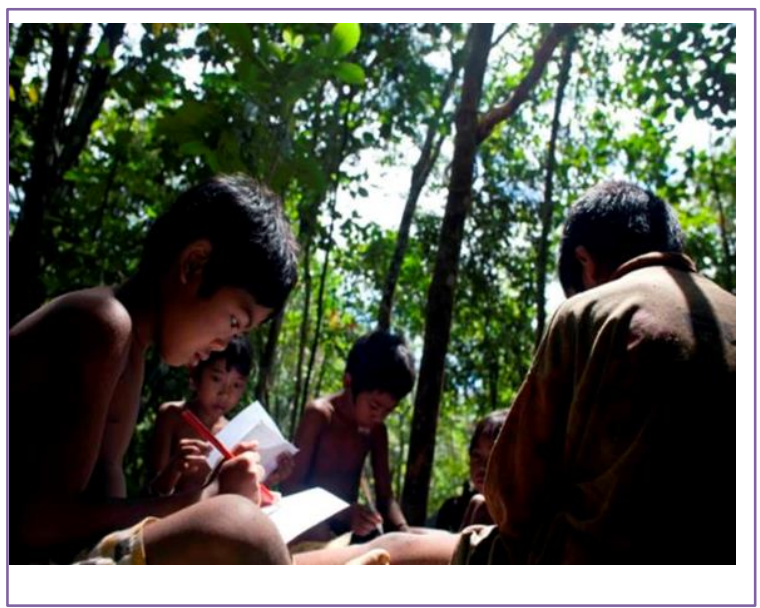

Gambar 1. Anak-anak Suku Anak Dalam sedang menggambar dan belajar menuliskan huruf.

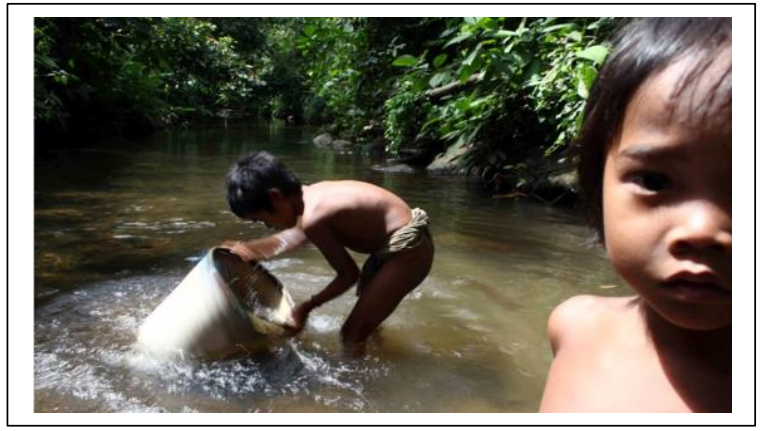

Gambar 2. Anak-anak Suku Anak Dalam membantu orangtua mereka, seperti membersihkan tong (ransel) berburu.

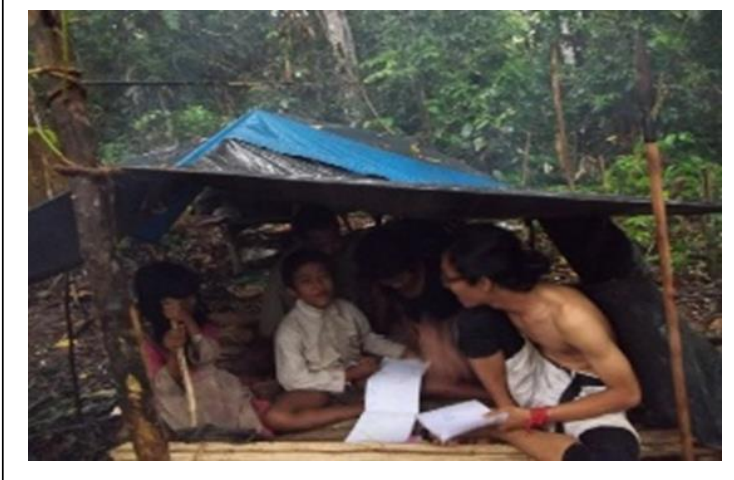

Gambar 3. Bujang Padek diminta menceritakan hasil gambarnya kepada teman-teman dan anggota Sahabat Belajar.

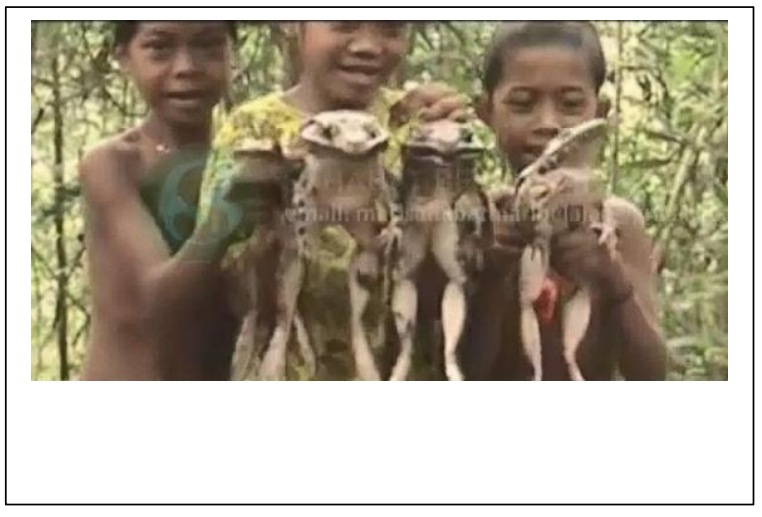

Gambar 4. Kodok besar menjadi mainan bagi anak-anak Suku Anak Dalam.

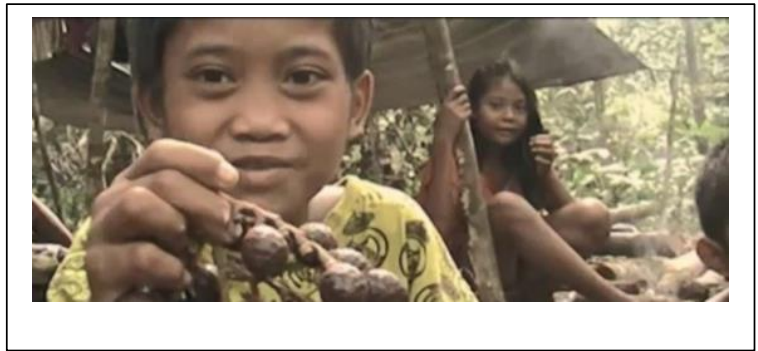

Gambar 5. Bujang menunjukkan jernang, hasil hutan biasa dicari Suku Anak Dalam, sebagiannya untuk mereka jual. 


\section{KESIMPULAN}

Anak-anak usia dini Suku Anak Dalam telah melalui proses literasi awal. Meskipun belum sampai pada tahap membaca, namun mereka telah melatih kemampuan berpikir mereka, pada hal-hal yang ada di sekitar mereka, melalui menggambar, menceritakan pengalaman, menghitung, dan membaca sebagaimana hal yang telah dibahas di pada bagian pembahasan.

Tantangan bagi Suku Anak Dalam kedepannya sangat berat. (Rosana, 2015), memberitakan rentetan peristiwa konflik yang terjadi antara Suku Anak Dalam dan warga lainnya. Intinya konflik-konflik itu terjadi akibat ketimpangan dalam berbagai hal. Upaya pengenalan literasi awal pada anak-anak Suku Anak Dalam setidaknya merupakan gerakan awal dalam pemecahan masalah konflik ini ke depannya, meskipun di Dharmasraya konflik belum terjadi sejauh itu.

Selanjutnya, penelitian pada anakanak Suku Anak Dalam sangat perlu dilakukan, mengingat penting dan mendesaknya kebutuhan mereka akan pendidikan dan pengetahuan. Namun bukan pengetahuan yang memusnahkan tradisi mereka, dan juga dibutuhkan upayaupaya dari generasi muda yang bersedia melakukan gerakan-gerakan seperti yang dilakukan Sahabat Belajar, yang mau melakukan pendekatan dan membangun literasi bagi anak-anak Suku Anak Dalam.

\section{UCAPAN TERIMA KASIH}

Terima kasih kepada Eko Jibril sebagai orang yang memberikan data lapangan dan pendekatan dengan Suku Anak Dalam. Kemudian kepada Sahabat Belajar atas upaya literasi pada Suku Anak Dalam.

\section{DAFTAR PUSTAKA}

Badan Pengembangan dan Pembinaan Bahasa. (2016). Kamus Besar Bahasa Indonesia V (Daring). In Jakarta: Balai Pustaka.

Fajriyah, L. (2018). Pengembangan Literasi Emergen pada Anak Usia Dini. Proceedings of The ICECRS, 1(3).

Henschke, R. (2017). Orang Rimba yang Bertahan di Tengah Hutan yang Semakin Habis. BBC Indonesia, BBC.

Kemendikbud. (2015). Peringkat Capaian PISA Indonesia Mengalamai Pengingkatan.

Rosana, F. C. (2015). Konflik Suku Anak Dalam Vs Warga Jambi Punya Riwayat Panjang. Koran Tempo.

Sager, S. (2008). The Sky is our Roof, the Earth our Floor: Orang Rimba Customs and Religion in the Bukit Duabelas region of Jambi, Sumatra.

Sahabat Belajar. (2013). Mari Sahabat Mari Belajar.

Wartomo. (2017). Membangun Budaya Literasi sebagai Upaya Optimalisasi Perkembangan Bahasa Anak Usia Dini. Universitas PGRI Yogyakarta., 1(2). 